\title{
Interest Rate Capping and Financial Performance of Commercial
}

\section{Banks in Kenya}

\author{
Kyalo Mutemi $^{1}$, Dr. Daniel Makori ${ }^{2}$ \\ ${ }^{1}$ Correspondent Author, School of Business, Kenyatta University, Kenya \\ ${ }^{2}$ Lecturer, Department of Accounting and Finance, School of Business, Kenyatta University, \\ Kenya
}

\begin{abstract}
Interest is the main source of income for commercial banks and therefore capping of interest rate may affect the performance of commercial banks and resort into measures such as downsizing to minimize the operational costs in order to remain sustainable. Put differently, the imposition of interest rate capping may have a bearing on the performance of commercial banks through interest margins generated. Against this background, the general objective of this study is to determine the effect of interest rate capping on financial performance of commercial banks in Kenya. Specifically, the study seeks to establish the effect of credit supply on financial performance of commercial banks in Kenya as well as to analyze the effect of asset quality on financial performance of commercial banks in Kenya. Moreover, the study seeks to determine the effect of cost of credit on financial performance of commercial banks in Kenya. The study is anchored on three key theories: Financial intermediation theory, fractional reserve theory of banking, the credit creation theory of banking; and theory of rational expectation. The study used quarterly secondary data from 2013 to 2017 collected from forty commercial banks licensed in Kenya. The choice of period is justified on the ground of data availability and the period when this study was started. The data was obtained from the bank's financial statements and other publications by the Central Bank of Kenya. To analyze the data, the study used descriptive analysis approach and Ordinary Least Square (OLS) regression method. The descriptive statistics and the regression results indicate that Interest rate capping has a positive effect on financial performance of commercial banks. It is evident from the results that capping interest rate has impacted commercial banks positively. In addition, the results reveal that the quality of assets measured by the share of Non-performing loans affects financial performance negatively. Further, it was evident that credit supply measured by gross loans and advances has negative effect on banks' financial performance. Based on the findings, this study recommends commercial banks to look into ways of reducing the proportion of non-performing loans in their books in order to improve their returns on assets. This can be achieved by assessing credit worthiness of individuals and companies before advancing loans. The cost of credit measured by the interest rate shows it has positive effect on financial performance and therefore the study recommends the government through the Central Bank to continue monitoring the cost of credit so as to make loans accessible to low income earners. This can contribute to increases in the uptake of loans thereby raising bank's profitability through interest payments. Commercial banks should also find alternative ways of increasing their interest income thereby improving returns on assets.
\end{abstract}

Key Words: Interest Rates, Interest Rate Capping, Commercial Banks Performance

DOI: 10.7176/ijcab.v3iIV.51 URN: nbn:de:0000ijcab.v3iIV.519

\section{Cite this Article:}


Mutemi, K., \& Makori, D. (2019). Interest Rate Capping and Financial Performance of Commercial Banks in Kenya. International Journal of Current Aspects, 3(IV), 119130. http://journals.ijcab.org/journals/index.php/ijcab/article/view/51

\section{INTRODUCTION}

The functions of commercial banks in any world economy cannot be overemphasized. The banks mobilize funds from depositors and disseminate the funds to the borrowers who in the end invest them in strategic areas of the economy. Generally speaking, banks act as linkage between borrowers and depositors. It is for this reason that banks' financial performance affects the economic wellbeing of a country directly (Wainaina, 2013). Financial performance is used to determine how well a firm uses its assets from the primary mode of business and be able to generate sufficient revenues. Accordingly, it is also used to measure the general health of a firm over a given period of time (Nyaga, 2009). Interest rate is the amount above the principal paid by borrowers for staying with the lenders funds for a certain period of time. Howard (2013) recognized three components of banks' interest rate as transaction cost, overheads and profits. Interest rate is the main revenue stream of the banking institution and the same has a lot of importance on how the economy performs. Interest rate remains one of the major and strategic tools at the disposal of central banks across the globe to influence and manipulate the economy. It is the mostly used macroeconomic tool by policy makers in the government to influence employment and inflation.

Interest rate cap on the other hand is maximum interest rate to be charged on funds lend by providers of finance to the borrowers. Howard (2013) noted that interest rate capping is usually a government intervention by legislation when it deems that the interest rate charged by commercial banks is too high and the market forces have failed to achieve equilibrium level. The measure is taken to ensure that the credit facilities are available even to the poor as the move reduces the cost of funds. The argument has been that the financial institutions make abnormal profits by charging exploitative interest rate and the government has not been able to achieve the desired effects in the economy. Interest rate caps have been widely used in different economies and to different levels as governments seek to achieve certain political and economic targets. Developed economies as well as developing ones have adopted interest rate cap or added more restrictions more so after the 2008 economic crunch (Maimbo \& Gallegos, 2014). The Monetary policy committee has the responsibility of setting the interest rate which affects unemployment and inflation of our country. Higher interest rate means higher cost of credit which means decline in affordability and the vice versa is true.

Interest rates capping is seen as a move to limit freedom of commercial banks as it suppresses their growth through strict restrictions on interest rates (Howard \& Nathan, 2013). Capping interest rates tends to create market inefficiencies as commercial banks are inclined to lend to customers demonstrating low risks thus creating market biases through a financing mechanism that was anticipated to have a positive impact. The caps can force most commercial banks opt to lend to the government which is considered low risk thus drawing away money from the public. Interest is the main source of income for commercial banks meaning that interest rates capping would render banks unprofitable and can take measures such as downsizing to cut off costs and remain sustainable (Ongore \& Kusa, 2013). As per Howard, and Nathan, 2013, interest rate cap is the control of interest rate paid to banks on loans advanced to borrowers. Interest rate capping and ceiling are synonymous and will be used interchangeably in our research. According to Maimbo and Henriquez (2014), interest rate cap controls the tendency of some banks to increase their interest yields particularly in markets where there is a market imperfection. Governments have used various methods of interest rate control far and widely for a long time to ease access and affordability of credit in 
the market to the most vulnerable in the economy, that is, the poor, youths, women and other minority and underprivileged groups. Through its legislative arm the government reintroduced the interest rate capping in Kenya at not over four percent, the base rate instituted by CBK (Banking Act, 2016).

Currently the monetary policy committee has set the Central Bank rate at ten percent (CBK Press Release, 2017). The law went ahead and stated that the banks will make known any loan fees to the borrower before granting the loan probably to deter exorbitant fees to cover the lost revenue in interest rate. The main argument for the introduction was that the interest charges were too high leaving businesses overburdened by cost of credit and also locking out other businesses and people accessing credit as they could not afford it. The legislators were looking into how they could control what looked like rogue banks which could not control themselves through market forces but needed legislative intervention to tame their predatory interest rate which gave them abnormal profits at the detriment of other economic sectors (Howard \& Nathan, 2013). The policy makers in this case intervene in form of interest rate cap to correct what they perceive as failure by market forces to keep the interest rate at reasonable levels (Howell, 2009). The policy makers also argue that introduction of the caps will bring in more financial inclusivity in that the groups which were initially locked out from accessing funds due to their high cost can now afford such services from financial providers. Just like any other market, the price of credit should be determined by demand and supply forces according to critics of interest rate cap (Howard, 2013). The normal demand and supply relationship will still apply when explaining how interest rates are charged.

High demand for credit means scrambling for the little available credit hence driving up the prices of the credit and vice versa (Ngwatu, 2014). Distortion of these forces will bring in unwanted effects like selective credit allocation, minimum limit on credit allocation and other forms of credit rationing. The interest rate capping will affect market driven interest rate if it is set below the prevailing equilibrium rate otherwise setting them above the market rate may not have much effects since market forces are not directly related to the controls according to research done by Federal Bank of Chicago (Samuel \& Gallegos, 2014). The report notes that when the caps are below the prevailing rates, the regulation will affect the market outcome. The banks will respond to the caps accordingly and it is such reactions which will ultimately determine whether the policy makers intended results will be achieved. In the USA the states operate differently in the way they control business operations including the banking sector. However the Federal Reserve Bank does have some sort of control on the banking institutions as well. The caps do exists in some states but varying in application and limits. The states of Arkansas and Connecticut have the lowest interest rate cap at $17 \%$ and Illinois with 99\% (Maimbo \& Gallegos, 2014). Only eight states do not have any form of interest rate control in their financial sector. This is an indication that interest rate cap is still popular tool among many government policy makers. A World Bank study in 2014 found that 24 countries in Sub-Saharan African had some form of interest rate controls, eight of them coming from WAEMU. The effective interest rate cap for WAEMU was initially set at $18 \%$ in 1997 and later dropped to 15\% in 2013 for banks (Mbengue, 2013). South Africa had initially abolished usury laws on small loans in 1993 but afterwards in 2007 reintroduced a cap on short term loan at 5\% per month. Zambia introduced its interest rate cap in 2013 and set it at $9 \%$ above the policy rate set by its central bank.

Financial Performance is measured by the results of organizational policies and operations expressed in monetary terms (Nazir, 2010). Performance is a major multidimensional approach aimed at achieving results and it has a strong connection with the organization strategic goals (Mwita, 2000). The interest rate ceilings will affect the bottom line of the 
banks since interest income is the major source of revenue for these banks. The law relating to interest rates capping was enacted in September 2016 despite its debate regarding its impact on commercial bank performance (Mbua, 2017). Before the bill came into a law, commercial banks used interest rates which were determined demand and supply forces based on the prevailing market conditions. Interest rates capping is seen as a move to limit freedom of commercial banks as it suppresses their growth through strict restrictions on interest rates. Capping interest rates tends to create market inefficiencies as commercial banks are inclined to lend to customers demonstrating low risks thus creating market biases through a financing mechanism that was anticipated to have a positive impact (Samuel \& Gallegos, 2014). The caps can force most commercial banks opt to lend to the government which is considered low risk thus drawing away money from the public. Interest is the main source of income for commercial banks meaning that interest rates capping would render banks unprofitable and can take measures such as downsizing to cut off costs and remain sustainable (Ngwatu, 2014). There is divided perception on the correlation between interest rates and credit issued to customers by the commercial banks. According to Nazir (2010) there is negative correlation between supply for credit and interest rates argue that when interest rates are high there are few borrowers. Interest rate capping was meant to protect customers by making bank loans cheaper.

The proponents of interest rate capping suggest that such moves will make credit less expensive and in the end open it up to the marginalized in the economy hence more financial inclusivity as a result of the credit growth. For instance when Zambia was introducing its cap at $9 \%$ above the policy rate in 2013 the policy makers reasons were that the rates charged at that time were too high, provision of credit to the underprivileged was low and debt trap amongst the citizens had worsened. The thinking behind interest rate control is to curtail the usury like interest rate among financial institution, to alleviate the burdensome nature of high credit prices among businesses and open up the credit facility to the poor to uplift their standards of living. However, research has shown that interest rate capping will hurt the poor more than the other groups as banks will stop lending to high risk individuals since the interest rate cannot cover the risk involved (Howard, 2013). Although the bigger banks can still remain profitable at low interest rate, the smaller one may fail to survive the caps and hence driving them out of the market hence squeezing the space of credit provision. New entrants may also not be attracted to markets with interest rate control which further creates space for illegal lenders. Empirical evidence on effects of interest rate capping does return negative impacts more often than not. Capera, et al. (2011) studies on Latin America indicated that some of the effects of interest rate cap were reduced access to funds by the low income earners. Colombia long history of interest rate cap had brought adverse economic effects which were felt longer even after reducing the controls. Kenya's banking sector has been resilient over the years. Total net assets increased by 2.1 percent from KSh 3,762.5 billion in the fourth quarter of 2016 to KSh 3,841.5 billion in the first quarter of 2017. This increase was attributable to 11.2 percent or KSh 19.0 billion increase in placements. The increase in placements is attributable to increase of the foreign currency deposits by some large foreign corporate engaged in on-going major infrastructure projects in the country. Loans and advances remained the main component of assets accounting for 58.5 percent in the first quarter of 2017, which was a slight decrease from 58.8 percent recorded in the fourth quarter of 2016.

\section{STATEMENT OF THE PROBLEM}

Financial performance of commercial banks is an important subject in policy making given the significant role commercial banks play in the economy. Commercial banks contribute to economic growth of the country by providing channels for investors to borrow funds for 
investment and also contribute to financial deepening (Nyaga, 2009). Banks financial performance in Kenya has significantly improved in the past five years. The performance of commercial banks improved with commercial banks recording improvement in pre-tax profit by 18.21 percent from Ksh 29.4 billion in the fourth quarter of 2016 to Ksh 34.4 billion in the first quarter of 2017. However, the increase in performance was due to decrease in banks expenses and not due to increase in income generated by commercial banks. As matter of fact, data from Central Bank of Kenya shows that total income decreased by 3.3 percent from KSh 117.9 billion in the fourth quarter of 2016 to KSh 114.0 billion in the first quarter of 2017.

Asset quality, on the other hand, as measured by the gross non-performing loans increased by 6.6 percent from Ksh 2126 billion as at the end of the fourth quarter of 2016 to Ksh 226.6 billion at the end of the first quarter of 2017. The dismal performance of commercial banks can be attributed to the introduction of interest rate capping law which came into effect in September 2016 (Kirui, 2017). Financial theory has it that controlling interest rate may impact the performance of financial institutions mostly commercial banks. However, proponents of interest rate capping argues that it enhances welfare enhancing in that individuals will get access to credit at lower and less burdensome rate and thereby improving their livelihoods (Hester \& Benjamin, 2016). Several factors may affect performance of commercial banks including exchange rates, interest rates, government spending as well as the growth of the economy. Given the importance of commercial banks in Kenya and the number of banks increasing over the years as well as increase in competition for customers, an analysis of the effect of interest rate capping on financial performance is important for policy makers. This can help policymakers in ascertaining the implication of such law and also provide information on how to improve the banking sector environment. Although there are studies that have analyzed the impact of interest rate on bank's financial performance among them (Odhiambo, 2013; Ng'aNg'a, 2017; Kiseu, 2017), these studies used descriptive research design but this study is different from the previous ones in that it uses Ordinary Least Squares (OLS) regression methods to analyze the data. In addition, this study contributes to the literature in that the variables of interest are measured in ratio as opposed to the absolute values used in the previous studies. This study therefore seeks to fill this research gap by using quarterly data to investigate the effect of interest rate capping on financial performance of commercial banks in Kenya

\section{OBJECTIVES OF THE STUDY}

The general objective was to analyze the effect of interest rate capping on financial performance of commercial banks in Kenya.

The specific research objectives of this study are:

i. To determine the effect of credit supply on financial performance of commercial banks in Kenya.

ii. To establish the effect of asset quality on financial performance of commercial banks in Kenya.

iii. To determine the effect of cost of credit on financial performance of commercial banks in Kenya.

\section{THEORETICAL LITERATURE REVIEW}

The study focuses on performance theories such as fractional intermediation theory, fractional reserve theory of banking, credit creation theory and theory of rational expectation.

\subsection{Financial Intermediation Theory}


This theory was propounded by Gurley and Shaw in 1960 and holds the bank like other nonbank financial institutions are merely financial intermediaries which consolidate deposits and lend them out. The theory of intermediation on financial matters is specifically relevant as it re-looks at the main goal of banks in any economy (Greenbaun \& Thaker, 2007). As a matter of fact, banks exists with fundamental aim of mobilizing deposits from the people who have the funds without any immediate use, and hence connects these people with those who actually need the funds (Berger, 2015). Of great importance in this case is that, the people who demand the funds may not be in a position to reach or meet with those who have the funds due to a number of factors. Firstly, the financial risks involved in the process where an individual may not with certainty trust another person probably if they are not proportionately acquainted may restrict borrowing from person in society. Secondly, it may be difficult for the people who need the funds to identify in the society those who have funds that can be used. In order to solve these uncertainties, banks came in to help link those who want to save and those who want to put into use funds for economic gain in both cases (Mallic \& Marjit, 2008). Financial intermediaries are defined as financial institutions which specialize in activity of buying and selling financial contracts and assets (Adrian \& Shin, 2010). They mediate between providers and customers of financial capital. Financial intermediation is defined as transfer of funds from financial agencies with surplus to financial agencies with deficit funds through the specified financial intermediaries. It analyzes the functions of financial intermediation and the manner it influences national economy as a whole and impact of government policies on various financial intermediaries, is based on information asymmetry and agency theories (Adrian, Etula \& Muir, 2014). Gurley and Shaw in 1960 conducted a study to examine the problematic correlation between banks and creditors. In this relationship between banks and borrowers the main factor analyzed is the bank selection procedure and tracking of issued loans and problems of moral hazard and adverse selection. Banks and non-financial institutions are merely financial intermediaries which consolidate deposits and lend them out. Financial intermediaries perform functions such as reducing transaction costs, providing information to the banks and engaging in debt renegotiation.

\subsection{Fractional Reserve Theory of Banking}

This theory originated many centuries ago before governmental monetary authorities were put in place (Bagus \& Howden, 2010). Its development was catalyst by bankers' realization that basically all depositors do not demand for payment at similar time. It became widely used in 1920 and its application highly appreciated by the Swedish Risks bank which was first world's central bank, formed in 1968 (Mbua, 2017). This theory holds that indeed banks are fundamental pillars in an economy as they provide a meeting ground for investors who has excess funds with borrowers who has deficit fund thus creating money reserves that can be used in funding development in the economy. Banks are required by monetary regulatory authority in their host country to hold certain fraction of cash provided by depositors available to carter for withdrawals. Larger percentages of banks are required to hold $10 \%$ of the total deposits as reserves for withdrawal purposes (Howard \& Nathan, 2013). The theory argues that, there could be no country that will have any reserves, may it be in local currencies or even in foreign currencies were it not for the existence of banks (Greenbaun \& Thaker, 2007). Precisely, when speaking of currencies in foreign denominations that is foreign currency, commercial banks facilitates the transition of foreign currencies into local currency of specific country through their central banks, this is a main milestone so far as creation of reserve is concerned. The significance of this theory to this study is based on the fact that the theory acknowledges that both regulated and unregulated financial institutions play a key role in the reserve creation process. This importance of both regulated and unregulated financial institutions in banking industry as long as regulation is concerned makes the "shadow banking" industry to attract more focus and attention as being 
instrumental in reserves creation in the entire economy (Berger, 2015). However, the major challenge to this concept is based on disclosure requirement principles. The question that emerges as if the entire banking industry is not regulated, then could it be possible for government and other relevant authorities to ascertain with confidence the magnitude of their contribution to the economy.

\subsection{The credit Creation Theory of Banking}

This theory was proposed by Alfred Mitchell-Imes and Anthropologist David Graeber in the $19^{\text {th }}$ century. It supports banks' existence in the economy irrespective of whether these financial institutions are unregulated or regulated. Fundamentally, this theory differs with the first two on the bases that banks existence is not for the purpose of "financial intermediations" but rather to lend money out for nothing (Berger, 2015). Based on this assertion, the theory propagates that as a result of banks "lending out funds in the form of loans, they end up creating a portfolio that keeps on increasing over time, hence enabling those who wants to borrow for various uses to have access to the funds (Cornett, McNutt, Strahan \& Tehranian, 2011). This theory proposes that banks can create money and they do not only lend out deposits that have been provided by depositors (Nazir, 2010). In its place, banks create bank deposits as result of bank lending. Therefore, the amount of money held by a bank does not depend on deposit taking activities. The bank's act of lending out money creates fresh purchasing power that was not there before (Ongore \& Kusa, 2013). The repayment of current debt decreases money as result of decreasing bank loans. The bank's capability to create new money is known as credit money. However, this theory fails to link the origin of funds that are advanced as loans and those that are deposited to the commercial banks as savings mobilized from the members of the public. It is vital to note that without credit accessibility; most of the economic activities such as entrepreneurship may fail to be successful because the funds provided by financial institutions act as the seeding synergy to conduct the business into levels of stability and propagate expansion respectively (Marllic \& Marjit, 2008).

\subsection{Theory of Rational Expectation}

This theory was first propagated by Muth in 1960 and later used by Pigou, Keynes and Hicks to explain business phenomena (Dietrich \& List, 2013). The theory goes that a future economic occurrence can be determined by the current situation. This theory propounded an economic concept whereby consumers make choices based on the current information, rational outlook and past experiences. It suggests that the current expectations in the economy may occur in future. This theory contrasts the perception that government policy influences consumer's decisions. For instance, we can forecast future interest rate by using current one and our expectations will ultimately drive them to expected value. Market perceptions remains to be one of the key determinants of actual outcome, say the case of bonds and shares for instance. Keynes refers to this as "waves of optimism and pessimism" that helped to determine level of business activities. Participants will behave in a way currently because of their perception in the future and such actions will validate the outcome of their expectations. Nazir (2010), in his study notes that unexpected changes in economic factors will lead to change in the future interest rate. Interest rate cap does away with speculation on the expected level of interest rate in future (Mbua, 2017).However, if the banks expect the issuance of loans to certain individuals to be adversely affected by interest rate cap, introduction of such controls will make banks to reevaluate loans issued to those groups perceived to be risky. The pessimism among commercial banks on the impact of interest rate cap to their profitability usually makes them to initiate cost cutting techniques 
like retrenching, closing down branches and reducing amount of unsecured loans hence curtailing availability of credit in the market.

\section{RESEARCH METHODOLOGY}

The study used a causal research design. The study targeted all commercial banks with comparable data as published by Central banks in 2018. There are 40 commercial banks licensed by Central Bank of Kenya. The banks under receivership and those that were acquired in the Course of study period were not considered in the analysis as they may not reflect true state of affairs of their performance. The population constitutes 40 commercial banks in Kenya that have been in operation in the last five years, licensed and registered under the Banking Act by Central Bank of Kenya. The survey targeted 40 commercial banks in Kenya. The study uses purely secondary data and there is no need of describing the target respondents. The study variables are deduced from the financial statements of the 40 chosen commercial banks operating in Kenya for the financial period 2013-2017. Secondary data as represented on the banks' financial statement is used in this study. The study mainly focuses on the changes in supply for loans and asset quality shown by total non-performing loans. The data analyzed is for three quarters before and after the capping of the interest rate. The data has been obtained from financial statements of the 40 commercial banks. Timely approved financial results are readily available on their websites. The loans book changes for each individual bank as shown in financial statements in the three quarters before and after the interest rate capping was analyzed. Descriptive analysis was conducted to review the performance of commercial banks before and after implementing the interest rate capping. Descriptive analysis and Ordinary Least Squares was used to analyze the data. Returns on assets, which measures financial performance is taken as a function of asset quality, credit supply, and the cost of credit.

\section{STUDY FINDINGS}

After conducting the diagnostic test on the data, OLS method was used to obtain the regression results.

Table 1: OLS Regression Results

Dependent Variable: Returns on Assets

\begin{tabular}{|lcccc|}
\hline Variable & Coefficient & Std error & t-statistics & p>t \\
\hline Asset Quality & -0.0199052 & 0.0131623 & -1.51 & 0.150 \\
Credit Supply & -0.0101303 & 0.004933 & -2.05 & $0.057^{*}$ \\
Cost of Credit & 0.0697289 & 0.0172295 & 4.05 & $0.001 * * *$ \\
Constant & 0.0094023 & 0.0049777 & 1.89 & $0.077^{*}$ \\
\hline $\begin{array}{l}\text { R-squared = 0.7922; Adj R- squared = 0.7532; F } 3,16)=20.33 ; \text { Prob> F }=0.0000 \\
*, * * * \text { denotes significance at 10\%, and 1\% respectively }\end{array}$ & \\
\hline
\end{tabular}

The OLS regression results presented in table 1 shows the $F$ statistics is 20.33 with a $P$ value of 0.0000 implying that the independent variables asset quality, credit supply, and the cost of credit jointly determine the dependent variable returns on asset. The regression results also indicate the measure of goodness of fit R-squared in 0.79 and adjusted R-squared is 0.75 implying 79 percent of the variation in bank's financial performance is explained by the independent variables. It is evident from the results that asset quality had negative but 
insignificant effect on financial performance. The regression results presented in table 1 showed that the coefficient of credit supply, measured by the loans deposit ratio had negative and significant effect on bank's financial performance. According to the result, a one percent increase in credit supply of leads to a decrease in banks' financial performance by 0.05 percent. The findings are in agreement with the results of Luqman (2014) which showed that the ratio of loans and advances to total deposits had negative but insignificant effect on bank's performance. Also, the findings are line with those of Muriithiet al. (2016) whose results indicated that credit risk has negative and significant effect on banks profitability. Similarly, the results indicated that asset quality has negative but insignificant effect on financial performance of commercial banks over the period under analysis. Specifically, the results show that one percent decrease in the ratio of asset quality due to increase in NPLS reduces commercial bank's financial performance by 0.01 percent. This outcome is in line with theoretical assertion that the accumulation of NPLs leads to a reduction in income earned by commercial bank's which ultimately affects the profit margin. Contrary to the theoretical expectation, the regression results indicate the cost of credit measured by the lending interest rate has positive effect on bank's financial performance. It is evident from the results that capping lending interest rate at 14 percent has impacted commercial banks positively. A reduction in lending interest rate by one percent increases financial performance by 0.07 percent holding all other factors constant. However, the results contradicts those of Ng'ang'a (2017) and Ericson (2018) who found out that interest rate capping had negative effect on bank's financial performance. In addition, the findings are in agreement with those of Nyaga (2009) whose findings indicated existence of a positive relationship between interest spread and financial performance. Therefore, the discussion of the above results shows that all the objectives of this study were met as reported in the regression outcome.

\section{CONCLUSIONS}

The findings indicated that credit supply has negative effect on financial performance. This is possibly due to increase in non-performing loans both to individuals as well as economic sectors. Although asset quality had insignificant effect on financial performance of commercial banks, it cannot be ignored because it had a negative sign. This implies that commercial banks need to put more effort in reducing the proportion of non-performing loans which is affecting their profits and hence their financial performance. The findings of the study also indicated that the cost of credit had significant positive effect on financial performance of commercial banks. This is in contrary to the theoretical postulation that controlling interest rate negatively affects the returns in the financial sector. Specifically, Interest rate capping being new policy to commercial banks, some of the banks adopted the wait and see approach. However, commercial banks have to find new ways on how to navigate the changes brought about by the new policy so that they remain afloat in the market while still making reasonable profits to cater for their operational costs.

\section{RECOMMENDATIONS}

Based on the findings that credit supply and asset quality had negative effect on banks financial performance, this study therefore recommends commercial banks to look into ways of reducing the proportion of NPLs in their books so as to improve the returns on assets. This can be achieved by assessing credit worthiness of individuals and companies before advancing loans. Commercial banks should also find alternative ways of increasing their interest income to improve their returns on assets. Moreover, the study recommends commercial banks to monitor the movement of loans deposit ratio and reduce the amount of loans and advances because increasing the amount of credit supply without controls may have a negative impact on the banks' financial performance. In addition, since the cost of credit showed to have positive effect on financial performance, the government through the 
Central Bank should continue monitoring lending interest rate so as to make loans accessible to low income earners. This can contribute to increases in the uptake of loans thereby raising bank's profitability through interest payments.

\section{REFERENCES}

Adrian, T., \& Shin, H. S. (2010). Liquidity and leverage. Journal of financial intermediation, $19(3), 418-437$.

Adrian, T., Etula, E., \& Muir, T. (2014). Financial intermediaries and the cross- section of asset returns. The Journal of Finance, 69 (6), 2557-2596.

Bagus, P., \& Howden, D. (2010). Fractional reserve banking: Some quibbles.

Bakun, W. H., Gómez Capera, A., \& Stucchi, M. (2011). Epistemic uncertainty in the location and magnitude of earthquakes in Italy from macro seismic data. Bulletin of the Seismological Society of America, 101(6), 2712-2725.

Banga, S. (2013). Socio-economic significance of commercial banks in India: With special emphasis on public sector Banks. International Journal of Advanced Research in Management and Social Sciences.

Barasa, S. N. (2010). Language, mobile phones and internet: a study of SMS texting, email, $I M$ and SNS chats in computer mediated communication $(C M C)$ in Kenya.

Berger, P. L. (2015). The sacred canopy. In Sociology of religion, 21-26, Routledge.

Bertossi, C., \& Duyvendak, J. W. (2012). National models of immigrant integration: The costs for comparative research.

Burghardt, G. M. \& William, S. (1916-2002). European Journal of Behavior Analysis, 4 (12), 123-126.

Cadogan, J. (2010). Comparative, cross-cultural, and cross-national research: A comment on good and bad practice. International Marketing Review, 27(6), 601-605.

Central Bank of Kenya, (2017). Credit officer survey April to June. Nairobi, Kenya.

Central Bank of Kenya. (2013). CBK annual Report 2012/2013: http://www.centralbank.go.ke

Cheruiyot, R. K. (2016). The effect of asset quality on profitability of commercial banks in Kenya. Published research projects MBA university of Nairobi.

Chowdhury, A. (2001). The impact of financial reform on private savings in Bangladesh.

Discussion Paper No. 2001/78, Helsinki: WIDER.

Cooper, D. R., \& Schindler, P., S. (2008). Business research methods.

Cornett, M. M., McNutt, J. J., Strahan, P. E., \& Tehranian, H. (2011). Liquidity risk management and credit supply in the financial crisis. Journal of Financial

Economics, 101(2), 297-312.

Crowley, J. (2007). Interest rate spreads in English-speaking African countries No. 7-101.

International Monetary Fund. 
Dietrich, F., \& List, C. (2013). A reason- based theory of rational choice. Nous, 47(1), 104134.

Fisher, I. (1930). The theory of interest.New York, 43.

Hester, T. R., Shafer, H. J., \& Feder, K. L. (2016). Field methods in archaeology. Routledge.

Howard, E. (2013). Garden cities of tomorrow. Routledge.

Howard, M., \& Nathan, A. (2013).Interest rate caps and their impact on financial inclusion.

Howell, D. C. (2009).Statistical methods for psychology. Cengage Learning.

Khalid, A., Haider, A., \& Rana, U. A. (2014). Credit risk exposure and performance of banking sector of Pakistan. Journal of Basic and Applied Sciences, 4(3), 240-245.

King, R. G., \& Levine, R. (1992). Financial indicators and growth in a cross section of countries, 819, World Bank Publications.

Kiseu, T.K. (2017). The effect of interest rate capping on the amount of credit issued by Commercial Banks in Kenya.

Levine, R. (1997). Financial development and economic growth: views and agenda. Journal of Economic Literature.

Lloyd, B.T. (2006). Money, banking and financial markets. Kansas University Publishers, 9th edition.

Lustig, N., \& Higgins, S. (2012). Fiscal incidence, fiscal mobility and the poor: a new approach.

Maimbo, S. M., \& Gallegos, C. A. H. (2014). Interest rate caps around the world: still popular, but a blunt instrument. The World Bank.

Mallik, G., \& Chowdhury, A. (2001). Inflation and economic growth: evidence from four south Asian countries. Asia-Pacific Development Journal, 8(1), 123-135.

Mbengue, D. M. (2013). The worrying trend of interest rate caps in Africa. CGAP blog. November, 11.

Mbua, S. N. (2017). Effect of interest rates capping by the Central Bank of Kenya on the banks listed on the Nairobi Securities Exchange (Doctoral dissertation, United States International University-Africa).

McConnell, C. R., Brue, S. L., \& Flynn, S. M. (2009). Economics: Principles, problems, and policies. Boston McGraw-Hill/Irwin.

Mugenda, A., \& Mugenda, O. (2003). Research methods, quantitative, and qualitative approaches, ACTS, Nairobi, Kenya.

Munir, R. I. S., Rahman, R. A., Malik, A. M. A., \& Ma'amor, H. (2012). Relationship between transformational leadership and employees' job satisfaction among the academic staff. Procedia-Social and Behavioral Sciences, 65, 885-890.

Muth, J. F. (1960). Optimal properties of exponentially weighted forecasts. Journal of the American statistical association, 55(290), 299-306.

Ng'ang'a, A. K. (2017). The impact of interest rate capping on the financial performance of commercial banks in Kenya. 
Ngele, N. M. (2016). The effect of interest rate on borrower's uptake of credit facilities in commercial banks in Kenya (doctoral dissertation, school of business, university of Nairobi.

Olusoji, M. O. (2003). Determinants of private savings in Nigeria: An error correction approach. NDIC quarterly, 13(3), 29-38.

Ongore, V. O., \& Kusa, G., B. (2013). Determinants of financial performance of commercial banks in Kenya. International Journal of Economics and Financial Issues, 3(1), 237-252.

Owusu, E. L., \& Odhiambo, N. M. (2013). Financial liberalization and economic growth in Ivory Coast.Investment Management and Financial Innovations, 10(4), 171-180.

Samuel, O. L. (2015). The effect of credit risk on the performance of commercial banks in Nigeria. African Journal of Accounting, Auditing and Finance, 4(1), 29-52.

Sangmi, M. U. D., \& Nazir, T. (2010).Analyzing financial performance of commercial banks in India: Application of CAMEL model. Pakistan Journal of Commerce and Social Sciences (PJCSS), 4(1), 40-55.

Surroca, J., Tribó, J. A., \& Waddock, S. (2010). Corporate responsibility and financial performance: The role of intangible resources. Strategic Management Journal, 31(5), 463-490.

Trochim, W., \& Kane, M. (2005). Concept mapping: An introduction to structured conceptualization in health care. International Journal for Quality in Health Care, 17(3), 187-191.

Tseganesh, T. (2012). Determinants of bank's liquidity and their impact on financial performance: empirical study on commercial banks in Ethiopia. Unpublished PhD dissertation).Addis Ababa University, Addis Ababa.

Wainaina, G.T. (2013). Effect of macroeconomic factors on commercial bank's lending to agricultural sector in Kenya. MBA Project, University of Nairobi.

Zaman, A., Gull, A., Nasir, R, Bilal. Pervaiz, Y., Riaz, M.A., \$ Ashraf, M. (2013).Interest rate fluctuations and financial outcomes of banking sector: A case study of Pakistan. Clear International Journal of Research in Commerce and Management, 4(7), 125-129.

This is an open-access article published and distributed under the terms and conditions of the $(\mathrm{cc}) \mathrm{EY}$ Creative Commons Attribution 4.0 International License of United States unless otherwise stated. Access, citation and distribution of this article is allowed with full recognition of the authors and the source.

Authors seeking to publish with an International Peer Reviewed Journal should consider www.ijcab.org by writing to the Editor at editor@ijcab.org. The articles must be quality, value adding and meet originality test. 